\title{
RAILROAD REORGANIZATION SINCE ENACTMENT OF SECTION 77
}

\author{
By De Forest Billyou $\dot{\dagger}$
}

Since the days when the newly developing railroads found themselves unable to complete projected construction within the limits of original finances or estimates, the roads have found it necessary to obtain relief from the demands of creditors. ${ }^{1}$ The procedure first utilized was voluntary ${ }^{2}$ or involuntary ${ }^{3}$ distribution of rolling stock and other assets among creditors. This crude method, and the resultant disruption of traffic, could not long continue once communities became dependent on rail transportation. Sensing the public inconvenience resulting from piece-meal seizure, and the inequitable effect upon creditors, a Georgia equity court, in 1845, directed, at the instance of the carrier, sale of a line as a whole, free of existing liens and claims, with distribution of the proceeds among creditors. ${ }^{4}$ For the reasons which, in 1845 motivated this Georgia court, insolvent railroads have typically been reorganized, rather than liquidated or dismembered, ${ }^{5}$

$\doteqdot$ A. B., 1942, LL.B., 1946, Columbia University; Member, New York Bar; Author, Corporate Mortgage Bonds and Majority Clauses, 57 Yale L. J. 595 (1948).

1. Cf. Rieger, The Story of the Western Railroads 22-31 (1926).

2. Cf. Marshall, Santa Fe 73 (1945).

3. It was such a seizure that an assignee sought to contest in Bowen v. Lease, 5 Hill 221 (N. Y. 1843); see 1 SwaINe, The Cravatr FirM 33 (1946).

4. Macon \& Western R. R. v. Parker, 9 Ga. 377 (1851) (Lumkin, J.) upholding the decree against collateral attack. Glenn, The Basis of Federal Receivership, 25 Col. I. Rev. 434, 441 (1925).

5. For eleven years following an 1867 amendment to the Bankruptcy Act [14 STAT. 535, \$37], liquidation was available in the federal courts on the petition of a cred-

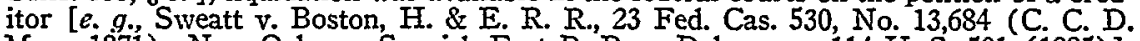
Mass. 1871); New Orleans, Spanish Fort R. R. v. Delarmare, 114 U. S. 501 (1885)]. This provision was repealed in 1878 [20 STAT. 99 (1878)] and, for reasons similar to those that motivated the Georgia court, this' unavailability of liquidation under federal bankruptcy law has continued, 30 STAT. 547 (1898) ( 44 by implication); In re Philadelphia \& Lewes Transportation Co., 114 Fed. 403 (E. D. Pa. 1902); 36 STAT. 839 (1910) (\$ 3 expressly); 47 STAT. 47 (1932) (expressly); 11 U. S. C. \$22(a) (1940). The eleven year availability of bankruptcy liquidation did not deter continued use of the receivership procedure. E. g., Bill v. New Albany \& Salem R. R., 3 Fed. Cas. 379, No. 1,407 (C. C. D. Ind. 1870) ; Allen v. Dallas \& Wichita R. R., 1 Fed. Cas. 465, No. 221 (C. C. W. D. Tex. 1878).

Bankruptcy liquidation has continuously been available to other utilities with a question, still existing, as to the distinction between a street railway and a railroad. In re Columbia Ry. Gas \& Electric Co., 24 F. 2 d 828 (E. D. S. C. 1928), aff'd, 27 F. 2d 52 (C. C. A. 4th 1928) with which compare In re Grafton Gas \& Electric Co., 253 Fed. 668 (N. D. W. Va. 1918). 
reorganization taking place under judicial, and at a later date, commission supervision. Thus developed the progenitor of corporate reorganization in America. ${ }^{6}$

These reorganizations long took the form of equity receiverships. In the nineteen-twenties, however, there developed growing criticism of these receiverships, largely because of the almost complete subversion in the proceedings of the policy of $\S 20 \mathrm{a}$ of the Interstate Commerce Act, ${ }^{7}$ contemplating ICC authorization for all new railroad secutity issues. Subsequent to enactment of that statute securities could be issued by a solvent road only after Commission application and authorization. However, in order to obtain authorization for issuance of the securities required to consummate a plan evolved in a railroad receivership, application was made to the Commission only as final phases of reorganization approached, and after the plan had been accepted by security-holder committees and passed upon by the court. Though the Commission never refused to grant the authorization sought, ${ }^{8}$ it protested that such delayed presentation made contemplative consideration impossible, since denial of an application would throw on the Commission the responsibility for ensuing reorganization delay. ${ }^{9}$ The Commission pointed out that its participation, since 1920, in railroad reorganizations, while all that the statute allowed, made little real contribution to the formulation of satisfactory plans and resultant capital structures. ${ }^{10}$

This protest was buttressed by suggestions of contemporary abuses in equity receiverships, ${ }^{11}$ ample evidence of lack of success of certain recent railroad receiverships, ${ }^{12}$ the contemporary financial debacle, and fears of further railroad financial difficulties. The combination of such factors led to the enactment, in the closing days of the

6. See First National Bank v. Flershem, 290 U. S. 504, 515, n. 7 (1934) ; FINLETter, The Law of BankRuptcy Reorganization 1-2 (1939).

7. 41 Stat. 494, §20a (1920), 49 U. S. C. \$20a (1940).

8. See Jacobs, The Interstate Commerce Commission and Interstate Railroad Reorganizations, 45 HARV. L. REV. 855, 876 (1932).

9. See Investigation of Chicago, M. \& St. P. Ry., 131 I. C. C. 615, 671-672 (1928); Chicago, M. \& St. P. Reorganization, 131 I. C. C. 673, 695-696, 699 (1928).

10. See Jacobs, supra note 8 , at 868 et seq.; IIIA Sharfman, The Interstate Commerce Commission 577-613 (1935).

11. See Stone, J, dissenting in United States v. Chicago, M., St. P. \& Pac. R. R., 282 U. S. 311, 331 (1931).

12. Of the 17 class $I$ roads which went through receivership subsequent to the 1920 enactment of $\$ 20 \mathrm{a}$ of the Interstate Commerce Act (Statistical Analysis of 31 Reorganizations of Class I Railways 1914-1933, inclusive, ICC Bur. of Statistics, Table I) seven had sought RFC loans within eight months of the creation of that agency. MOODY's RaILROADS lxxxviii (1932). 
Hoover administration, of $\S 77$ of the Federal Bankruptcy Act. ${ }^{13}$ There was an immediate rush to utilize $\$ 77$ : six class I roads filed petitions within six months of enactment. ${ }^{14}$ There was some indication, ${ }^{15}$ soon supported by a Supreme Court admonition, ${ }^{16}$ that $\S 77$ proceedings would be rapid. Subsequent events proved otherwise.

\section{The Scheme of Section 77}

Under $\S 77,,^{17}$ an interstate railroad, or creditors holding at least five per cent of the indebtedness of the road, may file, in the proper federal district court, a petition asserting insolvency of the road or an inability to meet debts as they mature and the desire to effect a plan of reorganization. The petition, when approved, gives the court exclusive custody of the debtor road and its property, wherever located. ${ }^{18}$ A hearing is then ordered at which a trustee for the debtor is appointed. ${ }^{19}$

Within six months after filing, or within such extended time periods as are granted by the court, the debtor is required to file a reorganization plan, and then public hearings on the plan are held by the Commission. Creditors, stockholders and other parties in interest are, under prescribed conditions, entitled to file plans. ${ }^{20}$ Following the hearings, the Commission may render a report approving a

13. 47 Stat. 1474 (1933); see Rodgers and Groom, Reorganizátion of Railroad Corporations under Section 77 of the Bankruptcy Act, 33 CoL. L. Rev. 571 (1933); Weiner, Reorganization Under Section 77: A Comment, 33 CoL. L. Rev. 834 (1933); Lowenthal, The Railroad Reorganization Act, 47 HaRv. L. REv. 18 (1933) ; Dodd, Reorganization Through Bankruptcy: $A$ Remedy for What, 48 HARV. L. REv. 1100 (1935).

14. Of these, the Chicago \& E. I., the Missouri Pacific, and the St. Louis, San Francisco had gone through equity receiverships between 1916 and 1922, the plan of the Chicago \& E. I. having been before the ICC on a $\$ 20 \mathrm{a}$ application. See In the Matter of Chicago \& E. I. Ry., 67 I. C. C. 61 (1921).

15. See Rodgers and Groom, supra, note 13 at 591-592; Hearings before Committee on the Judiciary on $H$. $R$. 6249 , 74th Cong., 1st Sess., 264-265 (1935) (hereinafter cited as Hearings on $H$. R. 6249).

16. See Continental Illinois Nat. Bank \& Trust Co. v. Chicago, R. I. \& Pac. R. R., 294 U. S. 648, 685 (1935). In proposing amendments to the statute in 1935 the draftsmen sought to ameliorate this urgency. See Hearings on $H . R .6249$ at 16, 22, 25 (1935) ; Craven and Fuller, The 1935 Amendinents of the Railroad Bankrniptcy Law, 49 Harv. L. Rev. 1254, 1262-1265 (1936).

17. Unless otherwise indicated, subsequent references to $\$ 77^{\circ}$ are to the section as presently amended, 49 STAT. 911 (1935) as amended, 11 U. S. C. $\$ 205$ (1943).

18. $\$ 77(a)$.

19. $\$ 77(c)(1)$.

20. $\S 77(d)$. 
plan, which may be different from any plan theretofore proposed. This approved plan is then certified to the bankruptcy court. ${ }^{21}$ Hearings are held by that body, at which objections to the certified plan may be presented. If the court finds that statutory requirements have been met, it may then approve the plan ${ }^{22}$ and direct the Commission to submit it to security holders for their vote. ${ }^{23}$ The results of balloting are certified to the court, which may confirm the plan if two-thirds of each voting class indicate acceptance, although it possesses, in appropriate circumstances, power to confirm the plan even if prescribed percentages have not accepted. ${ }^{24}$ When confirmed, the plan is, subject to appeal, binding on the debtor, its creditors and its stockholders. ${ }^{25}$

\section{EQUITY RECEIVERSHIP}

Enactment of $\S 77$ did not abolish the railroad receivership. Since the collapse of 1929 , fourteen Class I roads have been in receivership: seven of these proceedings, all instituted prior to eriactment of $\S 77$, were completed in equity; ${ }^{26}$ five of the fourteen transferred to $\S 77 ;{ }^{27}$ four of these having been instituted prior to enactment of $\S 77$; two remain uncompleted. ${ }^{28}$

In authorizing the issuance of securities called for by plans formulated in equity, the Commission did not raise any substantial question as to the propriety of the plans, which necessarily lacked the intimate commission participation contemplated by $\S 77$. However, in one case the Commission broke precedent and refused to grant the authorization sought. ${ }^{29}$ Authorization was eventually given after modification of the plan, ${ }^{30}$ the Commission even then indicating that

21. Ibid.

22. $\$ 77(\mathrm{e})$ first paragraph.

23. Ibid second paragraph.

24. Ibid third paragraph.

25. $\$ 77(f)$.

26. Minneapolis \& St. Louis R. R.; Missouri \& North Ark. Ry.; Mobile \& Ohio R. R.; Norfolk-Southern Ry.; Pittsburgh, Shawmut \& Northern R. R.; Seaboard Airline Ry. and Wabash R. R.

27. Central of Ga. Ry.; Florida East Coast Ry.; Rutland R. R.; St. Louis, S. F. Ry. and Wisconsin Central Ry., the Rutland proceedings having been instituted subsequent to enactment of $\S 77$.

28. Georgia \& Florida R. R. and Missouri \& Ark. Ry.

29. Minneapolis \& St. Louis R. R. Reorganization, 240 I. C. C. 57 (1940).

30. Minneapolis \& St. Louis R. R. Reorganization, 244 I. C. C. 357 (1941). 
it was not completely satisfied with the proposal. ${ }^{31}$ Subsequently there was developed a procedure whereby application was made to the Commission for its indication whether securities proposed in the plan would receive $\S 20 \mathrm{a}$ authorization. Favorable indication took the form of a conditional authorization. ${ }^{32}$ Then followed another application for final authority. ${ }^{33}$ By this procedure a serious pre-1933 objection to railroad equity receivership was met.

Section 77 did not expressly preclude railroad reorganization in equity proceedings and, indeed, certain provisions of $\S 77$ seemed to recognize its continued existence. ${ }^{34}$ The courts, however, have been reluctant to continue, or encourage, railroad reorganization in equity proceedings. There is some belief that $\S 77$ contemplates that the Commission shall have an intimate part in the formulation of all reorganization plans, and that the formalism of receivership reorganization should be abolished. On such grounds, one court dismissed an equity proceeding, ${ }^{35}$ indicating such a proceeding must be dismissed on filing of a petition meeting the requirements of $\S 77$, and may be dismissed sua sponte if the proceeding was instituted after enactment of $\S 77$. In another proceeding, it was indicated that $\S 77$ evidenced implied abolition of use of the equity receivership as an initial means to accomplish railroad reorganization..$^{36}$ As the latter court put if, the equity receivership was "outmoded but not outlawed." 37 However, this court allowed consummation of the receivership plan on the ground that relegation to $\S 77$ and reopening of the reorganization would be undesirable because of attendant delays.

\section{Id. at 387 .}

32. Seaboard Air Line Ry. Receivership, 257 I. C. C. 683 (1944); Wabash Ry. Receivership, 247 I. C. C. 581 (1941).

33. Seaboard Air Line Ry., 261 I. C. C. 689 (1946); Wabash Ry., 252 I. C. C. 611 (1942). For an explanation of the procedure followed in the Wabash proceeding see Sen. Rep. No. 25, pt. 6, 76th Cong., 1st Sess. 6-9 (1939). The procedure adopted a suggestion made in 1928 in Investigation of Chicago, M. \& St. P. Ry., 131 I. C. C. $615,672(1928)$.

34. $\$ 77(\mathrm{~g})$ (court empowered to dismiss $\$ 77$ proceedings if there "is undue delay"); $\$ 77(\mathrm{i}) ; \$ 77(\mathrm{n})$ (preference accorded personal injury claims in "equity receiverships of railroad corporations now or hereafter pending"); $\$ 77(\mathrm{p})$ (regulation of committee, proxy and deposit procedure). See also INT. REv. CoDE $\$ 142$ (tax returns); id. $\$ 1808$ (e) (3) (stamp taxes). 1944).

35. New England Coal \& Coke Co. v. Rutland R. R., 143 F. 2d 179 (C. C. A. 2d

36. Guaranty Trust Co. of New York v. Seaboard Air Line Ry., 53 F. Supp. 672, 697-700 (E. D. Va. 1943), aff'd., 145 F. 2d 40, $50-51$ (C. C. A. 4th 1944), cert. denied, 323 U. S. 797 (1945).

37. See Guaranty Trust Co. of New York v. Seaboard Air Line Ry., 53 F. Supp. 672,697 (E. D. Va. 1943). 


\section{Chapter XV and "Voluntary Adjustments" 38}

In the late thirties some roads, not then in bankruptcy or receivership, were unable to meet impending interest payments or maturity dates. This resulted from either the recession of $1937-38^{39}$ or from prolonged inability to meet fixed charges. ${ }^{40}$ For these roads, bank

38.

A. Under Chandler Act

(enacted 7/28/39,

Expired 7/31/40)

*Baltimore \& O. R. R.

*Lehigh V. R. R.

Wichita F. \& S. Ry.

**221 I. C. C. $585(7 / 37)$

Montana, W. \& S. R. R.

Chicago, M. \& G. R. R.

Peoria \& E. Ry.

ICC Order

**230 I. C. C. $243(11 / 38)$

$* * 236$ I. C. C. $325(12 / 39)$

239 I. C. C. $263(3 / 40)$

239 I. C. C. $303(3 / 40)$

B. Under McLanghlin Act (enacted 10/16/42, expired $11 / 1 / 45$ )

*Colorado \& S. Ry.

*Midland V. Ry.

ents"

Plan Approved General by Court Elements

29 F. Supp. $608 \quad 134$ A B

(D. Md. 1939), cert. denied, 309 U.S. 654 (1940)

$34 \mathrm{~F}$. Supp. $753 \quad 1 \mathrm{~A} \mathrm{~B}$

(D. Pa. 1940)

30 F. Supp. 7501

(N. D. Tex. 1939),

cert. denied, 309

U. S. 687 (1940)

32 F. Supp. $200 \quad 24$

(D. Mont. 1940)

Not reported 13

34 F. Supp. 332

(S. D. N. Y. 1940) 2 D

*Delaware \& H. R. R.

**254 I. C. C. $47(8 / 42)$

CCF Bankr. Dec. $134 \mathrm{~A}$

254 I. C. C. $271(3 / 43)$

II 54,303 (D. Colo. 1943)

*Baltimore \& O. R. R.

254 I. C. C. $239(3 / 43)$

51 F. Supp. $180 \quad 13$ A B C

(E. D. Okla. 1943)

51 F. Supp. 7632 A B C

(S. D. N. Y. 1943)

261 I. C. C. $51(3 / 45)$

63 F. Supp. 542

(D. Md. 1945), cert.

denied, 328 U. S.

871 (1946)

$14 \mathrm{ABD}$

*Class I Road.

**Plan initiated prior to enactment of statute.

***General elements in plan (not necessarily applicable to all classes affected by plan):

Modifications of bondholders' claims:

1. extension of principal or interest obligation.

2. extension of portion of principal obligation.

3 . reduction of interest.

4. interest made partly contingent.

Modifications of stockholders' interests:

A. restriction on use of income for dividend payments.

$B$. establishment or enlargement of sinking fund.

C. additional collateral made available as security for bonds.

$D$. bondholders given representation on the board.

39. See In re Lehigh Valley R. R., 34 F. Supp. 753, 755 (E. D. Pa. 1940).

40. See In re Baltimore \& Ohio R. R., 29 F. Supp. 608, 615-616 (D. Md. 1939). 
loans were unavailable and refunding operations could not be successfully carried out.

In such cases, attempts could be made, with bondholders' consent, to extend maturing bonds and reduce interest or to adopt some alternative method of readjusting maturities and debt structure. ${ }^{41}$ This, however, would require full satisfaction of contractual obligations to non-assenting bondholders. For two roads ${ }^{42}$ this was a real obstacle and as a result of their initiative, Chapter XV of the Bankruptcy Act ${ }^{43}$ was first enacted in $1939 .{ }^{44}$

Congressional reports on the bills that resulted in the new chapter expressly recognized that it was not to be an amendment or substitute for $\S 77 . .^{45}$ The enactment was to be available only to roads temporarily unable to meet their debts, whose general earning capacity had not been so impaired as to require the more thorough reorganization and modification of debt structure available under $\$ 77.46$

Under Chapter XV an embarrassed road, having prepared a plan for the adjustment of its obligations, and having secured assurance of the acceptance of the plan from creditors holding twenty-five per cent of all claims to be affected, would present the plan to the ICC. After making prescribed findings, ${ }^{47}$ the Commission could then authorize the modifications sought and the issuance of new securities proposed

41. In 1940 the ICC approved a plan whereby the Boston \& Maine R. R. exchanged some of its bonds, thereby extending maturities and reducing fixed charges. Boston \& Maine R. R., 240 I. C. C. 499, 511 (1940). See Hearings before Senate Committee on Interstate Commerce on H. R. 7121, 77th Cong., 2d Sess. 49, 52 (1942) (hereinafter cited as Senate Hearings on $H . R$. 7121).

42. The Baltimore \& Ohio R. R. and the Lehigh Valley R. R.

43. 53 STAT. 1134 (1939) (Chandler Act). See Will, Chapter XV of the Bankruptcy Act, 7 U. OF CHI. L. REv. 203 (1940); Will, The Voluntary Adjustment of Railroad Obligations, 7 LAW \& Contenr. ProB. 519 (1940).

44. See In re Baltimore \& Ohio R. R., 34 F. Supp. 154, 159 (D. Md. 1940); Hearings before Senate Committee on Interstate Commerce on $H . R .5407$, 76th Cong., 1st Sess. 48-49, 51, 54, 102, 107, 185 (1939) (hereinafter cited as Senate Hearings on $H . R .5704)$; Senate Hearings on H. R. 7121 at 21; 84th CoNG. REc. 6262 (1939).

45. H. R. REP. No. 358, 76th Cong. 1st Sess. 3 (1939) ; SEN. REP. No. 489, 76th Cong., 1st Sess. 1 (1939). To meet a suggestion that Chapter XV decisions might subsequently be applicable to $\$ 77$ the Senate Committee on Interstate and Foreign Commerce did advance amendments which, it felt, would assure that Chapter XV decisions would not constitute precedents under $\$ 77$. In doing so, it stated that "It is not the intention of these amendments to make inapplicable the principles of [the Boyd rule] ..."Id. at 7 .

46. 53 Srat. $1134,1135, \$ 710$ (2) (1939). See In re Baltimore \& Ohio R. R., 29 F. Supp. 608,612 (D. Md. 1939).

47. The Commission was required to find that (a) the carrier was not in need of $\$ 77$ reorganization and inability to meet its debts was expected to be only temporary and (b) in the light of probable prospective earnings the plan (i) was in the public interest, in the best interest of each class of creditor and stockholder, was feasible, financially advisable, and not likely to be followed by insolvency or reorganization or further adjustment, (ii) provided fixed charges which could be adequately covered by probable earnings and left adequate means for future financing and (iii) was consistent with adequate maintenance of property and proper performance of the railroads' obligations to the public as a common carrier. 53 STAT. 1134, $1135 \$ 710$ (2) (1939). 
in the plan. ${ }^{48}$ Armed with the assent of two-thirds of the creditors holding claims affected by the plan, including at least a majority of each affected class, the road could then petition the federal district court for an order approving the plan, alleging that it was unable to meet its debt, matured or about to mature. ${ }^{40}$ Thereupon a three-judge statutory court would be convened ${ }^{50}$ and, on notice to all persons in interest, $^{51}$ a hearing held. Following this, the court, after making prescribed findings, ${ }^{52}$ could approve and confirm the plan, ${ }^{53}$ as filed, or with such modifications as the court might propose. This would then be binding on all creditors holding claims or securities affected by the plan, ${ }^{54}$ and the need for purchasing the securities of non-assenters eliminated.

Under the 1939 statute, jurisdiction of the federal court to approve Chapter XV plans expired July 31, 1940 except as to petitions then pending. ${ }^{55}$ Under it, six readjustments were proposed and completed, two of which involved Class I roads. ${ }^{56}$

Although this enactment, and related hearings and reports, preceded the Supreme Court decision in the Los Angeles Lumber case, ${ }^{57}$ there seemed to be unanimous agreement that the statute would not conflict with, or modify, requirements of absolute priority. ${ }^{58}$ As the Congressional reports put it, court approval would not be granted where stockholders' participation continued "at the sacrifice of substantive rights of creditors." 59

48. 53 Stat. $1134,1135 \$ 710(1),(2)$ (1939).

49. Id. $\S 710(3)$.

50. Id. $\S 713$.

51. Id. $\$ 720$.

52. In addition to such formal findings as the existence of the requisite assents at the time of filing and submission of the plan and amounts of fees and expenses [id. $\$ 725(1),(2),(4-6)]$, the court was required to make, independently, the same findings required of the Commission [see note 47 supra] and the further finding "that the plan is fair and equitable as an adjustment, affords due recognition to the rights of each class of creditors and stockholders and fair consideration to each class thereof adversely affected, and will conform to the law of the land regarding the participation of the various classes of creditors and stockholders: ...". Id. \$ 725(3).

53. Id. $\$ 721$.

54. Id. $\$ 725$.

55. Id. $\$ 755$.

56. See note 38 supra, part A.

57. Case v. Los Angeles Lumber Co., 308 U. S. 106 (1939) (reversal of order approving $\$ 77 \mathrm{~B}$ plan allocating some of new securities to stockholder when claims of secured creditor exceeded valuation of property undergoing reorganization).

58. See Hearings before Committee on Judiciary on $H . R .5407,76$ th Cong., 1st Sess. 46, 55, 83 (1939) (hereinafter cited as House Hearings on $H . R .5407)$; Senate Hearings on H. R. 5407, 76th Cong., 1st Sess. 16, 83, 94 (1939) ; H. R. REP. No. 358, 76th Cong., 1st Sess. 3 (1939); SEN. REP. No. 489. 76th Cong., 1st Sess. 1 (1939). But cf. Senate Hearings on H.R. 5407 at $45-46$ (testimony of A. A. Berle, Jr., who viewed Chapter $\mathrm{XV}$ as a composition statute).

59. H. R. REP. No. 358, 76th Cong., 1st Sess. 3 (1939) ; see Senate Hearings on H. R. 5407, 189 (letter of Commissioner Eastman to Senator Wheeler). 
That all plans effectuated conformed to that prediction is more than doubtful. In at least three cases there was modification of contractual rights of secured creditors with no alteration of stockholders' interests. ${ }^{60}$ Other plans made use of such procedures or devices as restrictions on the use of income for dividends, establishment or enlargement of sinking funds, production of additional collateral security and bondholders' representation on the board. ${ }^{61}$ In these cases, determination as to whether holders of a particular security received adequate treatment could be a difficult task. ${ }^{62}$

In 1942, Chapter XV was re-enacted ${ }^{63}$ supposedly at the request of a holding Company ${ }^{64}$ which, having failed to meet fixed charges for several years, was unable to conduct refunding operations. ${ }^{65}$ Under the 1942 statute four readjustments of Class I roads were proposed and completed. ${ }^{68}$ In the course of re-enactment it was again recognized that absolute priority applied to Chapter XV proceedings. ${ }^{67 \cdot}$ However, only subsequent to re-enactment did it finally become clear that the Commission had no obligation to determine fairness of the plan as

60. Wichita F. \& S. Ry.; Montana, W. \& S. R. R.; and Chicago, M. \& G. R. R., cited note 38 supra. In the first two cases the plan originated as a conventional extension agreement which would not be binding on non-assenters. Since sufficient bondholders did not consent to make the plan financially feasible, the management used the assents to support a Chapter XV proposal which would be binding on non-assenters. In the third case the carrier applied to extend its first mortgage bonds for twenty-two years and to reduce interest by two per cent. No opposition to the management plan appeared in the last two cases.

61. See note 38 supra, last column.

62. For detailed analysis of the effect of the second Baltimore \& Ohio plan upon holders of $41 / 2,1960$ convertible bonds, see Brief for Petitioner (pp. 12-22) Philipps v. Baltimore \& O. R. R., 328 U. S. 871 (1945).

\section{56 Stat. 787 (1942) (McLaughlin Act). See also note 38 supra.}

64. This was the Delaware \& Hudson Co. See Senate Hearings on H. R. 7121 at $79,83,93$. The Baltimore \& Ohio $R$. $R$. was actively interested in securing enactment [Hearings before Senate Committee on Banking and Currency on RFC loan to Baltinore $\mathcal{E} O . R$. R., 80th Cong., 1st Sess. 131, 143-144, 146, 150, 502, 747-748, 750 (1947) ], an interest which was intentionally not disclosed. Id at 751 .

The corporation for which Chapter XV was ostensibly reenacted, the Delaware \& Hudson Co., was not a "carrier" as defined in $\$ 20(a)$ of the Interstate Commerce Act [41 STAT. 494 (1920), 49 U. S. C. $\$ 20$ (a) (1940)], but rather a non-carrier, liable or obligated on the securities of a carrier. As such, it would not come within the provisions of $\$ 77$ or the 1939 version of Chapter XV. But for a special provision in the 1942 version of Chapter XV [56 SrAT. 787, $789 \$ 711,11$ U. S. C. \$1211 (Supp. 1942)] it could have only utilized Chapter $X$ to effect a reorganization. Senate Hearings on $H$. $R$. 7121 at 93 ; Hearings before House Committee on Judiciary on $H$. $R$. 6840,77 th Cong., $2 \mathrm{~d}$ Sess. $30-35$ (1942) (hereinafter cited as Honse Hearings on H. R. 6840).

65. See Delaware \& Hudson R. R., 254 I. C. C. 239, 243 (1943).

66. See note 38 supra, part B. The 1942 statute expired November 1, 1945, following unsuccessful attempts to extend its life. H. R. 3429; H. R. REP. No. 1128; 91 Cong. Rec. 10,276 [all 79th Cong., Ist Sess. (1945)].

67. House Hearings on H. R. 6840 at 14, 38, 39; H. R. REP. No. 2177 at 5 ; SEN. REP. No. 1617 at 5 ; but see Senate Hearings on $H$. $R$. 7121 at 10-11 [All 77th Cong., 2d Sess. (1942)]. 
among security holders. ${ }^{68}$ In this respect, adjustments under Chapter $\mathrm{XV}$ differ greatly from $\S 77$ proceedings, where in the first instance, and before the plan is presented to the court, the ICC approves the entire plan, and also differ from larger Chapter $\mathrm{X}$ reorganizations where the SEC renders an advisory report to the court including its views as to compliance with priority requirements. That this militates against development of "fair and equitable" Chapter XV plans is reasonably clear, for, as one shrewd judge pointed out, the three-judge court, passing on Chapter XV plans, is not immune from the influences associated with Commission-authorized plans, already accepted by two-thirds of all affected creditors. ${ }^{69}$ Nor is this the only aspect of compulsion. Rejection of the plan will precipitate $\S 77$ proceedings, ${ }^{70}$ and modification of the plan might increase the cost of already costly solicitation and acceptance. ${ }^{71}$ These compulsive pressures on the threejudge statutory court are not unlike those which, heretofore, confronted receivership courts in considering reorganization plans that resulted from long and costly negotiation and study. ${ }^{2}$

So long as $\S 77$ reorganization is deemed a spectre, and to the extent that a court composed of three local federal judges feels that "continued successful operation [of a regional railroad] . . . is a matter of vital concern not only to the holders of hundreds of millions of its bonds but also for the public interest and convenience", ${ }^{73}$ judicial scrutiny of a Commission-authorized Chapter XV plan "independently of the extent of acceptance. . . and of any lack of opposition ... and of the fact that the Commission . . . has authorized the ...

68. See Midland V. R. R., 254 I. C. C. $271,281,282$ (1943); Delaware \& H. R. R., 254 I. C. C. 239,240 241, (1943) ; cf. dissent in Montana, W. \& S. R. R., 236 I. C. C. $325,338,339$ (1939).

69. See L. Hand, J. in Ewen v. Peoria \& E. Ry., 34 F. Supp. 332, 338 (S. D. N. Y. 1940). While the Commission never failed to authorize a Chapter $X V$ proposal, there was occasional dissent, $e . g$., on the ground that the proposal did not sufficiently extend maturities [Baltimore \& Ohio R. R., 261 I. C. C. 51, 90 (1945)], that the applicant was not in merely temporary financial difficulty [Montana, W. \& S. R. R., 236 I. C. C. 325,337 (1939) ], or that it needed reorganization rather than a mere "adjustment" [Chicago, M. \& G. R. R., 239 I. C. C. 263,279 (1940) ].

70. See In re Baltimore \& Ohio R. R., 63 F. Supp. 542, 545, 546, 551, 554, 560 (D. Md. 1945); In re Baltimore \& Ohio R. R., 29 F. Supp 608, 619, 627 (D. Md. 1939); In re Lehigh Valley R. R., 34 F. Supp. 753, 757 (E. D. Pa. 1940); In re Montana, W. \& S. R. R., 32 F. Supp. 200, 202 (D. Mont. 1940). Under some circumstances a Chapter $X V$ petition might have been rejected on the ground that $\$ 77$ should have been utilized. Cf. SEC v. U. S. Realty \& Improvement Co., 310 U. S. 434 (1940); New England Coal \& Coke Co. v. Rutland R. R., 143 F. 2 d 179 (C. C. A. 2d 1944).

71. When the 1938 Baltimore \& Ohio plan was submitted to the court the company had incurred expenses of $\$ 600,000$. See In re Baltimore \& Ohio R. R., 29 F. Supp. 608, 629 (D. Md. 1939).

72. See discussion supra.

73. See In re Baltimore \& Ohio R. R., 63 F. Supp. 542, 547 (D. Md. 1945). 
modification of securities as proposed . . ",74 seems little more than a pious hope. ${ }^{75}$

\section{REORGANIZATION UNDER $§ 77$}

Proceedings have been instituted under $\S 77$ on behalf of twentyfive class I roads. Fifteen proceedings have been completed, ${ }^{76}$ one has been dismissed ${ }^{77}$ and nine remain uncompleted. ${ }^{78}$ Since $\S 77$ has, for the last decade and a half, been the principal vehicle for railroad reorganization, review of its procedures and operation in some detail, and at least a glance at the results, is not out of place.

\section{Filing and Approval of Petition; Appointment of Trustee}

Section 77 is available not only to interstate railroads but to those roads which, while having property in but one state, handle traffic and equipment a considerable part of which is in interstate movement. ${ }^{79}$ Roads which render suburban or interurban service are relegated to Chapter $\mathrm{X}$ unless more than fifty per cent of operating revenues are derived from transportation of freight in standard steam railroad freight equipment. ${ }^{80}$

After approval of the petition, an early act of the reorganization court is the appointment of one or more trustees of the debtor's property. ${ }^{81}$ Under $\S 77$ as originally enacted the courts could, and did, appoint former officers of the debtor as trustees. This was deemed desirable to maintain continuity in management and operation. ${ }^{82}$

74. 53 Srat. 1134, §725(3) (1939); 56 Stat. 787, §725(3) (1942).

75. This is particularly significant under Chapter $\mathrm{XV}$, for while the plan was considered by a three-judge court convened pursuant to $\$ 266$ of the Urgent Deficiencies Act, 43 STAT. 936, 938 (1925), 28 U. S. C. $\$ 380$ (1940), unlike other proceedings brought before such a court, there was no appeal to the Supreme Court as of right, the only recourse being application for certiorari which was always denied. See note 38 sipra. No review may be had before a circuit court of appeals. Ackert v. Baltimore \& Ohio R. R., 115 F. 2d 455 (C. C. A. 4th 1940) cert. denied sub nom. Harvard State Bank v. Baltimore \& Ohio R. R., 311 U. S. 717 (1941).

76. Akron, C. \& Y. Ry.; Alton R. R.; Chicago \& E. I. Ry.; Chicago \& N. W. Ry.; Chicago G. W. R. R.; Chicago I. \& L. Ry.; Chicago, M. St. P. \& Pac. R. R.; Chicago R. I. \& Pac. Ry.; Denver \& R. G. W. R. R.; Erie R. R.; Minn. St. P. \& S. Ste. M. Ry.; New York, N. H. \& H. R. R.; St. Louis, S. F. Ry.; Spokane International Ry.; Western Pac. R. R.

77. St. Louis Southwestern Ry.

78. Central of Ga. Ry.; Central R. R. of N. J.; Duluth, S. S. \& At1. Ry.; Florida East Coast Ry.; Missouri Pac. Ry.; N. Y., O. \& W. Ry.; N. Y., S. \& W. R. R.; Rutland R. R.; Wisconsin Central Ry.

79. $\$ 77(\mathrm{~m})$.

80. In re Chicago, N. S. \& M. R. Co., 131 F. 2 d 458 (C. C. A. 7th 1942).

81. $\S 77(\mathrm{c})(1)$.

82. See Hearings before Honse Committee on Judiciary on $H . R .6249,74$ th Cong., 1st Sess. 51, 109 (1935). Prior to the 1935 revision it was held that appointment of a trustee was not required and operation of the property could be left in the control of the existing management, subject to court supervision. Lansdown v. Faris, 66 F. $2 \mathrm{~d}$ 939 (C. C. A. 8th 1933). 
But, as it was also felt this might perpetuate the conditions which brought about insolvency, the statute was amended to require that, on appointment of a former officer as trustee, there be appointed a cotrustee without such prior affiliation. ${ }^{83}$

\section{Jurisdiction of the Reorganization Court}

Operation of the road is continued by the trustee under general and special instructions of the court. In so far as operations affect the public, ICC jurisdiction is respected, ${ }^{84}$ and even where ICC jurisdiction is not immediately involved, the court may hold hearings to determine public sentiment. ${ }^{85}$

Creditors are greatly affected by the operational policies of the road while undergoing reorganization, possibly even more directly than by operational policies of a solvent road. Their participation in the reorganized road may depend, in part, on the use made of the property subject to their lien, and the earnings of that property during reorganization. While abandonment of a branch line will reduce the security value of that line to that of scrap it may also eliminate a deficit property from a mortgage division, thereby increasing earnings of that division ${ }^{86}$ and increasing its possible participation in reorganization. Acquisition of new equipment may increase earnings and income or improve competitive position, ${ }^{87}$ but if acquisition be financed by the sale of equipment trust certificates, a priority will result ${ }^{88}$ and corporate debt will be increased. ${ }^{89}$ If the equipment be purchased with cash, working capital will be reduced, directly affecting the security

\section{3. $\S 77(\mathrm{c})(1)$.}

84. A district court may authorize discontinuance of service only after the Commission has issued the order required by $\$ 1(18)$ of the Interstate Commerce Act [41 Stat. 477 (1920), 49 U. S. C. \$ 1(18) (1940) ] has been made by the ICC. Thompson v. Texas Mexican Ry., 328 U. S. 134 (1946) (suit to enforce, on lessee-debtor, lessor's termination of lease); In re Boston Terminal Co., 71 F. Supp. 472 (D. Mass. 1947) (petition of mortgage trustee to foreclose).

85. Cf. In re Denver \& R. G. W. R. R., 32 F. Supp. 244 (D. Colo. 1940) (petition of trustee to abandon branch line; plenary court hearing held prior to ICC application).

86. Cf. In re Central of Ga. Ry., 42 F. Supp. 940 (S. D. Ga. 1942).

87. Cf. Van Schaick v. McCarthy, 116 F. 2d 987 (C. C. A. 10th 1941) (petition of trustee to use accumulated cash for installation of traffic control equipment).

88. $\S 77(\mathrm{j})$.

89. In re St. Louis, S. W. Ry., 17 F. Supp. 68 (D. Mo. 1936), aff'd. sub nom. Bankers Trust Co. v. Henwood, 88 F. 2d 163 (CCA 8th 1937) (objection to trustee's motion, seeking authority to use accumulated cash for construction of new equipment and urging, instead, the sale of equipment trust certificates, overruled); cf. In re Denver \& R. G. W. R. R., 47 F. Supp. 484 (D. Colo. 1942), appeal dismissed on consent, 142 F. 2d 451 (C. C. A. 10th 1944) (creditors objection to use of accumulated cash for payment of bankruptcy obligations overruled). 
of any creditors having a lien on accumulated earnings. ${ }^{90}$ Thus, during the course of a $\S 77$ proceeding, the court is constantly confronted with interrelated operational, financial and legal questions.

Since the objective of a $\$ 77$ proceeding is to effect a "fair and equitable" plan of reorganization, the court, in making each decision, must consider the contribution or detraction each decision will make to an ultimate plan. In like manner, before allowing a secured creditor to pursue or exercise his contractual rights unhampered, the court will consider the effect of such exercise and will enjoin whatever will adversely affect formulation of a plan. ${ }^{01}$

The "property" of the debtor which, with related liens, may be subjected to the power of the reorganization court, is an enlarging concept. The court may direct that apropriate steps be taken to bring into the proceeding a solvent, partly-owned subsidiary; ${ }^{92}$ or a solvent lessor of property operated by the debtor $;^{93}$ and it would seem that the court possesses some power to prevent those who are neither creditors, nor claimants, from taking steps which would tend to disrupt or impede reorganization. ${ }^{94}$ So broad is the power of the court that only a specific provision of $\S 77^{95}$ protects those having interests in rolling stock, operated on the debtor's lines pursuant to a lease or conditional sale, from receiving treatment similar to that accorded ordinary secured creditors. $^{96}$

\section{Claims; Filing of Plan}

The category of "claims" which may be dealt with by a $\$ 77$ plan is large. It includes obligations of the debtor under operating agree-

90. Cf. In re Wisconsin Central Ry., 64 F. Supp. 251 (D. Minn. 1946), aff'd sumn 120m. Empire Trust Co. v. United States Trust Co., 165 F. $2 d 829$ (C. C. A. 8th 1948).

91. Continental Bank \& Trust Co. v. Chicago, R. I. \& P. Ry., 294 U. S. 648 (1935) (exercise of power to sell pledged collateral enjoined). If the enjoined creditor be injured by a decrease in value of the pledged collateral he will be entitled to assert a claim, as a secured creditor, to the extent of his damage. In re New York, N. H. \& H. R. R., 147 F. 2d 40, 47-48 (C. C. A. 2d 1945), on remand, 64 F. Supp. 487 (D. Conn. 1945).

92. See N. Y. Trust Co. v. N. Y. \& Greenwood Lake Ry., 156 F. 2d 701, 703, 704 (C. C. A. 3d 1946).

93. In re Pittsburgh Ry., 155 F. 2d 477 (C. C. A. 3d 1946); cert. denied, sub nom. Philadelphia Co. v. Guggenheim, 329 U. S. 731 (1946) (Chapter X); 60 HARv. L. Rev. 140 (1946). But cf. Benton v. Callaway, 165 F. 2d 877 (C. C. A. 5th 1948), cert. granted March 15, 1948.

94. In re Central of Ga. Ry., 48 F. Supp. 445 (S. D. Ga. 1942), aff'd Central Hanover Bank \& Trust Co. v. Callaway, 135 F. 2d 592 (C. C. A. 5 th 1943) (injunction continued against sale of stock of subsidiary in which debtor owned equity, which stock was pledged to secure bonds on which debtor had no obligation).

95. $\$ 77(\mathrm{j})$.

96. See Friendly, Amendment of the Railroad Reorganization Act, 36 CoL. I. REv. 27 at 42,43 (1936). 
ments or leases, ${ }^{97}$ and debts which, while not obligations of the debtor, are secured by liens on the property of the debtor. ${ }^{98}$ These claims may properly be treated by an offer of securities of the reorganized company. A filed proof of claim constitutes prima facie evidence of the claim ${ }^{99}$ and the statute does not contemplate that each claimant seek formal allowance of his claim. ${ }^{100}$ A creditor or trustee may make timely objection to any claim, ${ }^{101}$ but it is on the basis of the filed proofs that plan-formulation proceeds.

Upon the corporate debtor is the obligation to file, within six months of approval of the petition, the debtor's proposed plan. ${ }^{102}$ However, early in the administration of $\S 77$, earnings and operations were at such a low level that there was reluctance to prepare plans formulated on the assumption that then current earnings were indicative of the future, ${ }^{103}$ and time to file plans was freely extended. ${ }^{104}$ Some courts even suggested that a period of operation under $\S 77$ was necessary, or desirable, to determine a basis for reorganization or future operation. $^{105}$

\section{Commission Approval of a Plan}

Following hearings, the Commission is required to report on a plan, which may be different from any plan proposed, and, indeed may

97. See In re Chicago, M., St. P. \& Pac. R. R., 36 F. Supp. 193, 205-210 (N. D. IIl. 1940), aff'd sub nom. Group of Institutional Investors v. Chicago, M., St. P. \& Pac. R. R., 318 U. S. 523, 546-555 (1943). At times, reorganization of the lessor may take place "in connection with" reorganization of the lessee, in which case the properties may be consolidated. See Old Colony Bondholders v. New York, N. H. \& H. R. R., 161 F. 2d 413, 420-421 (C. C. A. 2d 1947).

98. In re Chicago, R. I. \& Pac. Ry., 50 F. Supp. 835, 860-861 (N. D. Ill. 1943); Chicago, R. I. \& Pac. Ry. v. Fleming, 157 F. 2d 241, 248-249 (C. C. A. 7th, 1946) (bonds of Little Rock \& Hot Springs \& Western R. R.) ; In re Missouri Pac. R. R., 39 F. Supp. 436, 445-6 (E. D. Mo. 1941) (same).

99. Gardner v. New Jersey, 329 U. S. 565, 573 (1947). A mortgage trustee may file a claim for all the bonds for which it is trustee. $\$ 77$ (c) (7). If it fails to do so within a reasonable time individual bondholders may file claims. Blumgart v. St. Louis, S. F. Ry., 94 F. 2d 712 (C. C. A. 8th 1938), cert. denied, 304 U. S. 567 (1938).

100. $C f . \S 77(\mathrm{c})(7)$.

101. E. g., In re Wisconsin Cent. Ry., 63 F. Supp. 151 (D. Wis. 1945) (objection to claim for interest on interest accrued but unpaid during receivership and $\$ 77$ proceedings).

102. $\$ 77(\mathrm{~d})$.

103. See House Hearings on $H$. R. 6249, at 76, 87, 95, 280; 52 ANN. ReP. ICC 11 (1938) ; Swaine, Present Status of Railroad Reorganization and Legislation Affecting Them, 18 N. Y. U. L. Q. REv. 161, 164 (1941); Rhyne, Work of the Interstate Commerce Commission in Railroad Reorganization Proceedings under Section 77, 5 Geo. Wast. L. Rev. 749, 776 (1937).

104. 48 ANN. REP. ICC 18 (1934); Craven and Fuller, supra note 16, at 1261 n. 25.

105. In re Central of Ga. Ry. 57 F. Supp. 419, 420 (S. D. Ga. 1944); Int re Central of Ga. Ry., 42 F. Supp. 940, 944, 945 (S. D. Ga. 1942). Contra: In re New York, N. H. \& H. R. R., 54 F. Supp. 595, 603 (D. Conn. 1943). 
be a plan proposed initially by the Commission, provided, in its opinion, it meets requirements of the statute. ${ }^{106}$

(a) Extent and nature of existing claims and liens. While the existence of claims or liens may be recognized by all, there may be dispute as to their nature, extent or priority. In the past, these disputes have frequently been initially raised at Commission hearings on the plan. As these are largely questions of law, Commission determination of these disputes, as embraced in its plan, are regarded as "tentative" 107 and may be reviewed by the district court. ${ }^{108}$ This has resulted in duplication of effort and, where the tentative determinations are found wrong, there ensues time-consuming shuffling between Commission and court. ${ }^{109} \mathrm{~A}$ partial solution to this wasteful process has developed, whereby the Commission, when aware of such disputes, approves a plan with alternative features, either one to be invoked depending on subsequent judicial resolution of the dispute. ${ }^{110} \mathrm{~A}$ more satisfactory procedure, and one coming to be used with greater frequency, is for creditors or the trustee to submit the controversy to the reorganization court in advance of, or contemporaneous with, the Commission hearing. ${ }^{111}$ This judicial determination, subject to review, is then determinative of the issue.

(b) The plan and creditors. Of chief importance to creditors is the treatment accorded their claims. This is dependent on the capitalization of the reorganized road and their participation therein.

(i) Capitalization of the reorganized road. The Commission, in approving a plan, establishes a "maximum capitalization", which, in its opinion, the reorganized road can sustain."112 This "maximum capitalization" is then allocated among participating security holders. Although earnings are deemed most significant in determining ap-

106. $\$ 77(d)$.

107. Ecker v. Western Pac. R. R., 318 U. S. 448, 489, 503 (1943).

108. Id. at 489-503; Group of Institutional Investors v. Chicago, M. St. P. \& Pac. R. R., 318 U. S. 523, 568-569 (1943).

109. On remand of a plan it is not necessary for the Commission to proceed de novo as though a plan were to be formulated for the first time. Chicago, R. I. \& Pac. Ry. v. Fleming, 157 F. $2 d$ 241, 245 (C. C. A. 7th 1946), cert. denied, 329 U. S. 780 (1946). The practice has developed whereby the court, in advance of approval or disapproval, refers the plan back to the Commission for "limited purposes." In re New York, N. H. \& H. R. R., 147 F. 2d 40, 44, 50 (C. C. A. 2d 1945), cert. denied, 325 U. S. 884 (1945) ; In re New York, N. H. \& H. R. R., 161 F. $2 d$ 413, 418-419 (C. C. A. 2 d 1947), cert. denied, 331 U. S. 859 (1947).

110. E. g. New York, N. H. \& H. R. R. Reorganization, 257 I. C. C. 9 (1944), approved, In re New York, N. H. \& H. R. R., 54 F. Supp. 631, 636-7 (D. Conn. 1944)'

111. E. g., In re Central of Ga. Ry., 58 F. Supp. 807 (S. D. Ga. 1945), rev'd sub nom. Liberty National Bank \& Trust Co. v. Bankers Trust Co., 150 F. 2d 453 (C. C. A. 5th 1945); In re Wisconsin Central Ry., 63 F. Supp. 151 (D. Minn. 1945).

112. Cf. $\$ 77$ (b) (4). 
propriate capitalization, ${ }^{113}$ Commission reports on $\$ 77$ plans typically, and somewhat illogically, recite in addition to evidence on earnings, evidence on all the factors enumerated in the valuation provision of $\S 77$ (e). ${ }^{114}$ The weight accorded earnings by the Commission in arriving at a "maximum capitalization" is not discernable, ${ }^{115}$ but there is substantial reason to feel that what is accomplished is an ad hoc determination. ${ }^{116}$

113. Reconstruction Finance Corp. v. Denver \& R. G. W. R. R., 328 U. S. 495, 516 (1946) ; Group of Institutional Investors v. Chicago, M., St. P. \& Pac. R. R., 318 U. S. 523, 540-541 (1943); cf. Consolidated Rock Products Co. v. DuBois, 312 U. S. 510, 525-526 (1941) ( $\$ 77 \mathrm{~B}$ proceedings). With an estimate of future earnings it is deemed possible to establish a capitalization which a given enterprise may reasonably be expected to service. See Note, 51 Yale L. J. 85, 88-96 (1941). This has not been a simple task in railroad reorganization. Since 1930 the railroads successively experienced full effect of the collapse of the late twenties, severe highway competition of the early thirties, drought and dust-bowl conditions of the thirties, the recession of 1937-38, followed by unprecedented wartime traffic and earnings. As a result, for the years 1930-1946 annual railroad income available for charges has ranged from a low in 1938 of $\$ 503$ million to a high in 1942 of $\$ 1,618$ million with an annual average of $\$ 912$ million. MOODY's RaILROADS a6 (1947).

Of interest are the "probable future annual earnings" available for fixed charges assumed by the Commission in some $\$ 77$ proceedings:

Actual annual earnings available for fixed charges 1940-1946**

Road Assumed by

C. \& N. W. the IC **

C. M. St. P. \& P.

C. R. I. \& P.

$\$ 14,625,000 \quad \$ 42,426,259$ (1943)

$15,894,000 \# \quad 52,481,624(1943)$

$11,000,000 \quad 37,672,445(1943)$

Low (year)
$\$ 11,224,665$ (1940)
$14,866,993(1940)$
$8,417,779(1940)$
$5,616,230(1946)$

Annual

Average

$\$ 22,629,400$

$30,007,782$

$23,648,810$

$35,926,210(1943)$

$21,037,878$

* See Hearings before Honse Committee on Judiciary on $H . R .2857,78$ th Cong. 199 (1943).

** Moody's RaIlroads 1091, 1271, 1124, 973 (1947).

\# Estimate filed by a party to the Commission proceeding.

114. $\$ 77(\mathrm{e})$, last paragraph. Following enactment, this valuation provision was castigated as a ". . . compromise between plain good sense and supposed good law ...". 2 Bonbright, THe Valuation of Property 878-881 (1937). Plans were subsequently approved based on records containing no evidence as to reproduction cost [Ecker v. Western Pac. R. R., 318 U. S. 448, 483 (1943); cf. In re Chicago \& N. W. Ry., 126 F. 2d 351, 363 (.C. C. A. 7th 1942), cert. denied, 318 U. S. 793 (1943) (mere Commission consideration of reproduction cost is adequate statutory compliance)], and the contention that the provision required valuation of debtor's property was rejected. In re Chicago \& N. W. Ry., 35 F. Supp. 230, 244 (N. D. I11. 1940). One court charitably observed that the provision was intentionally vague in order to make upsetting of a Commission valuation difficult. See In re Western Pac. R. R., 34 F. Supp. 493, 500 (N. D. Cal. 1940).

115. But even this "maximum capitalization" is not a fixed figure for it has been held that if, before consummation of the plan, old securities are retired, new securities theretofore allocated to retired securities need not be distributed to the remaining creditors but may remain unissued, or issued and retained in the treasury. In re Chicago, R. I. \& Pac. Ry., 67 F. Supp. 547, 553 (N. D. I11. 1945), aff'd sub nom. Chicago, R. I. \& Pac. Ry. v. Fleming, 157 F. 2 d 241 (C. C. A. 7th 1946), cert. denied,
329 U. S. 780 (1946).

116. "Although it has been said that the ICC has adopted a valuation based on earning power in capitalizing reorganized railroads, neither the language used nor the results reached by the Commission seem to justify this conclusion." Note, 54 HARV. L. Rev. 655 656 (1941). Cf. Frank, J. dissenting in Old Colony Bondholders v. New York, N. H. \& H. R. R., 161 F. 2d 413, 448-450 (C. C. A. 2d 1947); Swaine, A Decade of Railroad Reorganization under Section 77 of the Federal Bankruptcy Act, 56 HARV. L. REV. 1037, 1193, 1198-1201 (1943); Note, 51 YALE L. J. 85, 94-95 (1941) ; Friendly and Tondel, The Relative Treatment of Securities in Railroad Reorganizations Under Section 77, 7 LAW \& CoNTEMP. PROB. 420, 426 (1940); Warner, Some Financial and Economic Problems in Railroad Recapitalizations, 7 LAw \&
Contemp. Prob. 438, 438-439 (1940). 
Section 77 plans have typically excluded stockholders from participation in the reorganized road with the finding that their interest is of "no value". 117 The practice has been upheld as in accord with the statute. 118

(ii) Participation of creditors in the reorganized road. The principal problem of equity reorganizations was to prepare a plan that would bind non-assenters. The same problem faced draftsmen of the first federal reorganization statute. One troublesome aspect of this was that of priority.

Long prior to the federal reorganization statutes it was held that a reorganization that did not allow junior creditors to participate in the reorganized company was unfair and inequitable to these creditors if old stockholders were allowed to participate to an extent greater than justified by a new contribution to the reorganized company. It was held also that such a plan, even though consummated, did not preclude these creditors from asserting a debt claim against the reorganized company. ${ }^{119}$ This standard, it has been held, was incorporated in some of the federal corporate reorganization statutes. ${ }^{120}$

Before 1933 there was speculation, but little decisional law, as to whether priority was applicable as between classes of creditors. ${ }^{121}$ Speculation also revolved about what must be given to a senior class

\section{7. $\S 77(\mathrm{e})$, second paragraph.}

118. Ecker v. Western Pac. R. R., 318 U. S. 448, 475-489 (1943) ; Reconstruction Finance Corporation v. Denver \& R. G. W. R. R., 328 U. S. 495, 516-520 (1946). While $\$ 77(\mathrm{~b})(3)$ clearly contemplates use of stock warrants, plans which excluded stockholders from participation, and made no provision for the issue of warrants, have been upheld. Ecker v. Western Pac. R. R., supra at 477, 478-479, 481-482; Group of Institutional Investors v. Chicago, M. St. P. \& Pac. R. R., 318 U. S. 523, 536-546 (1943).

119. Northern Pac. Ry. v. Boyd, 228 U. S. 482 (1913) ; cf. Louisville Trust Co. v. Louisville, N. \& Chi. Ry., 174 U. S. 674 (1899) (bill by unsecured creditor to examine foreclosure proceedings) ; Chicago, $R$. I. \& Pac. v. Howard, 7 Wall. 392 (U. S. 1868) (suit by judgment creditor to levy on fund reserved for distribution to stockholders of insolvent debtor); see Kansas City Terminal Ry. v. Central Union Trust Co., 271 U. S. 445, 455 (1926).

120. \$ 77B, 48 Stat. 912 (1934) [Case v. Los Angeles Lumber Products Co., 308 U. S. 106, 115-116 (1939)] ; \$ 77 [Group of Institutional Investors v. Chicago, M. St. P. \& Pac. R. R., 318 U. S. 523, 541-542 (1943)] ; Chapter X, 52 STAT. 883 (1938) [Marine Harbor Properties Inc. y. Manufacturers Trust Co., et al., 317 U. S. 78, 85 (1942)] ; but $c f$. Chapter XI, 52 Stat. 905 (1938) [SEC v. U. S. Realty \& Improvement Co., 310 U. S. 434 (1940)].

121. See Swaine, Reorganization of Corporations: Certain Developments of the Last Decade, 27 CoL. L. REv. 901, 907 (1927) (urging applicability of "the Boyd doctrine"); Bonbright and Bergerman, Two Rival Theories of Priority Rights of Security Holders in a Corporate Reorganization, 28 CoL. L. REv. 127 (1928) (the classical statement of "absolute priority" but recognizing that completed reorganizations showed a distinct leaning toward a rule of relative income position) ; 2 BonBriger, Judicial Valuation of Property 872-873 (1937) (urging applicability of classical absolute priority). 
before a junior class might participate. ${ }^{122}$ Not until formulation of post-1933 reorganization plans, then unique in the capitalization reductions accomplished, were these questions pointed for judicial decision.

In 1936 the Supreme Court, in a $\S 77 \mathrm{~B}$ proceeding, held that junior creditors might be excluded when the market value of the corporate assets was found to be less than the amount of the senior claim. ${ }^{123}$ This exclusion of junior creditors, while analogous to exclusion of stockholders in the Los Angeles Lumber case ${ }^{124}$ was, however, not a decision based on doctrinal priority, but rather on statutory provisions empowering the court to eliminate from participation those creditors whose claims were found to be valueless. ${ }^{125}$ Similarly, in $\S 77$ reorganizations, junior creditors, like stockholders, may be denied participation if the Commission finds the junior claims are of "no value" ${ }^{126}$ or, more realistically, that the approved "maximum capitalization" will be exhausted in allocations to the seniors. ${ }^{127}$

(iii) Allocating new securities to secured claims. Secured claims that have participated in consummated plans fall into two general categories: (1) those secured by liens on operating property and (2) those secured by pledges of collateral.

Participation by claims secured by liens on operating property has generally been based on earnings of the liened property. Thus, claims secured by a senior lien on a very profitable division have, by some plans, been left undisturbed. ${ }^{128}$ At the other end of the scale, claims secured by a senior lien on a weak division, or by a junior lien on a division with earnings scarcely equal to the amount necessary to meet interest on the senior lien have, by some plans, been alloted securities having a total face, par or stated value considerably less than the claim, and are subject to exclusion from participation

122. Cf. Bonbright and Bergerman, supra note 121, at 131 (advocating the allocation of ". . new securities whose fair [cash market] value is estimated or roughly equal to the par of the principal plus defaulted interest.").

123. In re 620 Church Street Corp., 299 U. S. 24 (1936) ; accord, In re Witherbee Court Corp., 88 F. 2d 251 (C. C. A. $2 \mathrm{~d}$ 1937), cert. denied sub nom. Klee Corp. v. Roosevelt, 301 U. S. 701 (1937).

124. Case v. Los Angeles Lumber Products Co., 308 U. S. 106 (1939) (\$ 77B).

125. $\$ 77(\mathrm{~b})(4) ;(\mathrm{e})(1)$.

126. Ecker v. Western Pac. R. R., 318 U. S. 448, 475-476 (1943) (unsecured creditors); see Reconstruction Finance Corp. v. Denver \& R. G. W. R. R., 328 U. S. 495, 509 (1946); Swaine, supra note 116 at 1212-1213.

127. Cf. Ecker v. Western Pac. R. R., 318 U. S. 448, 476, 483, 488 (1943).

128. E. g., in the New Haven reorganization, left undisturbed were the Harlem River \& Port Chester R. R. 4's, 1954, Naugatuck R. R. 1st 4's, 1954, and the Providence Terminal 1st 4's, 1956. 
if the Commission finds the claim, because of its remote chance to participate in earnings, of "no value". ${ }^{129}$

Participation by a collaterally secured claim, most of which have been RFC held, has usually been based on value of the collateral. ${ }^{130}$ Claims secured by pledge of collateral consisting of debtor's securities having a market value in excess of the claim have been paid the full amount of the claim in cash, ${ }^{131}$ or alloted securities having a cash value substantially equivalent to the claim. ${ }^{132}$ Where the claim is secured by collateral having a lesser market value it has been alloted securities that would have been allocated to the collateral, ${ }^{133}$ the unsatisfied portion being regarded as an unsecured claim.

Claims well secured by pledged collateral were generally created when open-market sale of railroad bonds was possible only at substantial discounts. Their chief object was to facilitate the making of secured loans without the necessity of creating a new bond issue for

129. See note 125 supra. The text is addressed to a situation where one property is the only security for two mortgages, a situation which, because of its simplicity, is not common in Class I reorganizations. More common are overlapping liens on contiguous or non-contiguous properties where one mortgage may be a first lien on a western division and a junior lien on parts of an eastern division. $\$ 77$ plans have sought to eliminate such lien complexities by creating system mortgages. In doing this some appropriate formula must be used to determine the contribution made to the system mortgage by release of the lien of the old divisional mortgage and to establish an appropriate basis for allocating new system securities to old lienors. See Consolidated Rock Co. v. Du Bois, 312 U. S. 510, 520-525 (1941).

130. The old Erie General Convertible 4's, 1953, in addition to being a junior lien on the Erie System, were secured by pledge of the stock of six companies, the stock of two being recognized as of value, the others being regarded as valueless. The court approved the plan over the objection of the Convertibles that the plan failed to allocate sufficient fixed interest bonds to them. The allocation was based on the Commission's appraisal of the assets of the companies whose stock was pledged. In re Erie R. R., 37 F. Supp. 237, 248-251 (N. D. Ohio 1940).

131. The Milwankee plan, as finally approved by the Commission, provided cash payment for the collaterally secured RFC claim. Chicago, M., St. P. \& Pac. R. R Reorganization, 254 ICC 707 (1943).

132. In the Chicago \& N. W. reorganization, the RFC had a claim of $\$ 49,184,905$ which was secured by the pledge of collateral having a face value of $\$ 101,813,800$. For this, it was allotted a note and new securities, described in note 135 infra, having a face value of $\$ 83,701,008$. See In re Chicago \& N. W. Ry., 35 F. Supp. 230, 241-243, 259 (N. D. Ill. 1940), aff'd, 126 F. 2d 351, 369-370 (C. C. A. 7th 1942), cert. denied, 318 U. S. 793 (1943).

133. The Western Pacific plan as approved by the Commission treated three collaterally secured claims as follows:

\begin{tabular}{lrrrc} 
Creditor & Total Claim & $\begin{array}{c}\text { Collateral* } \\
\text { (face amount) }\end{array}$ & $\begin{array}{c}\text { New Securities } \\
\text { (total allocation) }\end{array}$ & $\begin{array}{c}\text { (collateral: total } \\
\text { collateral) (allocation: } \\
\text { total allocation) }\end{array}$ \\
RFC & $\$ 3,862,870$ & $\$ 10,750,000$ & $\$ 1,063,693$ & $1: 1.767$ \\
RCC & $2,590,924$ & $4,000,000$ & 395,792 & $1: 4.749$ \\
A. C. James & $6,249,750$ & $4,249,000$ & 420,480 & $1: 4.470$ \\
\cline { 2 - 5 } & $\$ 12,703,544$ & $\$ 18,999,000$ & $\$ 1,879,965$ &
\end{tabular}

* Collateral consisted of Western Pac. R. R. Gen. \& Ref. Bonds which were a first lien on property found, by the Commission, to have a value and earning power sufficient to justify issue of the allocated securities. See 318 U. S. at 456 (1943). 
sale at such a discount. ${ }^{134}$ The treatment accorded such a claim seems inconsistent with the treatment frequently accorded the bond secured by a senior lien on a profitable line. That bond is frequently alloted new securities which, while they have a face value equal to the face amount of the claim of the bond, have a lesser cash market value. ${ }^{135}$ The difference in treatment makes the well collateralized claim a safer and more desirable security, in $\S 77$ proceedings, than a mortgage bond. Though a junior creditor may object to a plan on the ground that it fails to meet standards of fairness, in that it accords unduly favorable treatment to other participants, ${ }^{136}$ the apparent conflict in treatment nevertheless continues unexplained, chiefly because the allocation accorded the well collateralized claim has been generally unopposed. In a similar manner, senior lienors have accepted without protest allocations of new securities having a total face value equal to the old claim, although selling at a discount. They have not objected to these allocations, ${ }^{137}$ although junior participation is based, in part, on property subject to the senior lien. ${ }^{138}$ As a result, while language

134. See Hatch, A Form of Depression Finance-Corporations Pledging Their Ozon Bonds, 47 HARv. L. REv. 1093, 1093-1096, 1111 (1934). The mortgages of recently reorganized roads deter recreation of such generously secured claims. These mortgages contain covenants that the mortgagor will not pledge the bonds so that they exceed debt secured by such a pledge by more than ten per cent of the total bonds issued. E. g., First Mortgage, Denver \& R. G. W. R. R., Art. IX, \& 21 (1947).

135. In the Chicago \& $N$. W. reorganization the RFC held a collaterally secured claim of $\$ 49,184,905$. For this it received a $\$ 25,000,000$, 15 year secured serial note of the reorganized company. Treating this note as the equivalent of cash, the allocation of the $\$ 24,184,905$ residuum of the claim, as compared with allocations made to the 1st and Ref. Bonds, was as follows:

Allocated Securities

1st \& Gen. Bonds

2nd Mtge. Income Bonds

$5 \%$ Pfd. ( $\$ 100$ par)

Common (at $\$ 100$ stated value)

\begin{tabular}{|c|c|}
\hline \multicolumn{2}{|c|}{$\begin{array}{l}\text { Face, par or stated value of new } \\
\text { securities allocated for each: }\end{array}$} \\
\hline $\begin{array}{l}\$ 1,170 \text { of residual } \\
\text { RFC claim }\end{array}$ & $\begin{array}{l}\text { 1st \& Ref. Bond having } \\
\text { a total claim of } \$ 1,170\end{array}$ \\
\hline $\begin{array}{r}\$ 376.52 \\
586.07 \\
751.95 \\
1,125.31\end{array}$ & $\begin{array}{r}\$ 153.00 \\
231.50 \\
304.50 \\
481.00\end{array}$ \\
\hline & $.00^{*}$ \\
\hline
\end{tabular}

* Market value of these securities, as of May 17, 1947, was $\$ 484.46$. See Hearings before Senate Committee on Interstate and Foreign Commerce on S. 249 , 80th Cong., 1st Sess. 453 (1947).

136. See Insurance Group Committee v. Denver \& R. G. W. R. R., 329 U. S. 607, 618 (1947).

137. Thus, the only objections on behalf of creditors to the Milwankee and Denver plans as approved by the Commission were those of trustees of the bond issues that received the smallest allocation. The seniors, apparently, did not urge that permitting these junior issues to participate was an act of benevolence. Cf. Swaine, supra note
116 , at 1210 .

138. In the Milwankee proceeding it was held that the 50 Year Mortgage 5's had a second lien on lines west of the Missouri River and a third lien on lines to the east and that the Convertible Adjustment 5's were secured by a still inferior lien on the same properties. The Fifty Year bonds received for their $\$ 1195$ claim securities having, on consummation day, a market value of only $\$ 870$. Nevertheless, the Adjustment 5's were allotted common stock. 
of $\S 77$ cases accords lip service to application of "absolute priority" among classes of creditors, actual results are otherwise. ${ }^{139}$

As recently as 1937, the principal advocate of "absolute priority" recognized it as a standard of elementary land mortgage law not then fully recognized in corporate reorganization. ${ }^{140}$ One aspect of the plea that it be recognized in the reorganization field was accepted in the form of denial of stockholder participation where such participation would result in what was deemed inadequate allocation to creditors. In sharp contrast to this acceptance is the failure to apply a similar standard among ranks of creditors. Since the standard was originally urged as appropriate for the recognition of creditors' rights, the failure of senior creditors to insist on its application in recent railroad reorganizations, and their acceptance of allocations less than those justified by the standard, may indicate permanent eclipse in corporate reorganization of "absolute priority" among classes of creditors.

\section{Court Approval of the Plan}

On other than legal aspects of the plan, Commission determinations are conclusive if the Commission report indicates consideration of some evidence material to its determinations, and at least some of the evidence supports that determination. ${ }^{141}$ If requirements of the

139. As did Prof. Bonbright and Mr. Bergerman, the following table assumes that the market value of the new securities provides one means of analyzing the fairness of the allocations of a consummated reorganization plan.

Old Security

Total Claim per
$\$ 1,000$ Bond*

Denver \& R. G. W. R. R.

Rio G. W. 1st Trust 4's $\$ 1320$

Rio G. W. Consol. 4's

Rio G. Junct. 1st 5's

Denver \& R. G. Consol. 4 's

Denver \& R. G. Consol. 4I/2's

Ref. \& Imp. 5's

Ref. \& Imp. 6's

General 5's

$\$ 1320$
1330
1379
1340
1382
1412
1495
1461

1461

1161

1143

1133

1267

Chicago \& N. W. Ry. 1st \& Ref. 4r/2's

Chicago, G. W. R. R. 1st 4's 1959
Par Received

Market Value of New Securities Apr. 15, 1947
$\$ 1320$

1330

1379

1340

1382

1412

1495

146

1161

1144

1147

1266
$\$ 1022$

443

1084

535

552

462

489

14

May 17, 1947

$\$ 484$

420

302

1013

* Less any cash allocated.

140. See 2 BonBRIGHT, op. cit. supra note 121, at 867-870.

141. Ecker v. Western Pacific R. R., 318 U. S. 448, 466-477 (1943) ; Chicago, R. I. \& Pac. R. R.v. Fleming et al., 157 F. 2d 241, 244 (C. C. A. 7th 1946), cert. denied, 329 U. S. 780 (1946). Subsequent to the Western Pacific and Milwankee decisions it was suggested that Commission determination might be conclusive only upon questions "strictly of public interest." Swaine, supra note 111, at 1049-1051. Later decisions indicate that the district court has no greater power of review over questions not "strictly of public interest." In $r e$ New York, N. H. \& H. R. R., 147 F. 2d 40, 46 (C. C. A. 2d 1945), cert. denied, 325 U. S. 884 (1945) (Commission finding that equity of stockholders has no value, relative allotment to two participating 
statute have been met, court approval follows. ${ }^{142}$ Under such limited review it has been futile to urge that the security structure adopted by the Commission fails to reflect an appropriate capitalization. ${ }^{143}$

\section{Balloting; Confirmation and Consummation}

Following court approval, the plan is submitted by the Commission to security holders for their vote. ${ }^{144}$ Submission need not be made to classes excluded from participation, nor to those classes of creditors whose interest the Commission, and court, have found will not be adversely and materially affected by the plan. Submission to stockholders is required in only a few circumstances and has rarely been necessary. If the requisite vote is obtained, confirmation is automatic. ${ }^{145}$

Though there is generally a lapse of time between court approval and balloting, if the court were asked immediately upon approval of a plan to confirm it over the objections of non-assenters, there would be "a re-examination of the plan to assure that those who dissent have had fair and equitable treatment... [and re-examination would] center upon the rights of those who rejected the plan." 140 Since the Supreme Court has indicated that "the elements which make the plan fair and equitable cannot be the basis for reasonably justified rejection," 147 it would seem that this supposed immediate re-examination would necessarily be directed, not to elements of the plan, but rather to such obsolescence of presuppositions and assumptions as are brought about by changed conditions. ${ }^{148}$

classes) ; In re New York, N. H. \& H. R. R., 54 F. Supp. 595, 604-605 (D. Conn. 1943) (relative allotment to two participating classes.

142. ". . . the District Court acts concerning the plans only upon the issues specifically delegated by subsection (e). As to these, its powers are negative. It may veto the plan in its entirety but may improve it only by suggestion." Ecker v. Western Pacific R. R., 318 U. S. 448, 474 (1943).

143. E. g., Group of Institutional Investors v. Chicago, M., St. P. \& Pàc. R. R., 318 U. S. 523, 544-545 (1943), where the court rejected the argument that the proportion of stock in the capital structure, with a concomitant loss of tax saving in the form of interest deductions, justified upsetting the plan. Some flexibility is preserved in the plan by including a provision empowering the court to "cure defects and supply any omission or reconcile any inconsistency." In re Chicago, M., St. P. \& Pac. R. R., 36 F. Supp. 193, 214-216 (D. I11. 1940).

144. $\$ 77(\mathrm{e})$, third paragraph.

145. Ibid.

146. See Reconstruction Finance Corp. v. Denver \& R. G. W. R. R., 328 U. S. 495, 534 (1946).

147. Id. at 535; In re Chicago, R. I. \& Pac. R. R., 160 F. 2d 942,945 (C. C. A. 7 th 1947). This exclusionary rule, it has been noted, gives no independent status to the "reasonable rejection" test [Frankfurter, J. dissenting in Reconstruction Finance Corp. v. Denver \& R. G. W. R. R., note 146 sipra at 545, 548; Swaine, supra note 116, at 1054], a result justifiable for administrative reasons. 60 HARv. L. REV. 211, 293 (1946).

148. Reconstruction Finance Corp. v. Denver \& R. G. W. R. R., 328 U. S. 495, 535 (1946); In re Chicago, R. I. \& Pac. R. R., 160 F. 2d 942, 945-949 (C. C. A. 7th 1947). 


\section{Changed Conditions}

It is recognized that the courts possess the power to stay consummation of reorganization plans because of changed conditions. ${ }^{149}$ In recent years, numerous attempts have been made to stay consummation of $\$ 77$ plans on the ground that increased earnings, subsequent to Commission approval, constituted "changed conditions" justifying a stay. These attempts have uniformly been unsuccessful, chiefly because what was asserted as "changed conditions" was regarded as too temporary in nature to be accorded significance, and was usually found to have been contemplated, envisaged, and considered by the Commission when it approved the plan. ${ }^{150}$

\section{Dismissal of Proceedings}

Section 77 was originally regarded as a means of accomplishing reorganization somewhat more rapidly ${ }^{151}$ than through use of the equity receivership, ${ }^{152}$ and the suggestion has been made that the statute is not to be regarded as a moratorium statute. ${ }^{153}$ At the time

149. Swaine, supra note 116 , at $1221-1224$ and inferentially by the cases cited note 150 infra. Cf. Knight v. Wertheim \& Co., 158 F. $2 d 838$ (C. C. A. 2d 1946), cert. denied, 331 U. S. 818 (1947).

150. Insurance Group Committee v. Denver \& R. G. W. R. R., 329 U. S. 607, 611-621, 627 (1947) (appeal from Circuit Court order staying consummation); Reconstruction Finance Corp. v. Denver \& R. G. W. R. R., 328 U. S. 495, 520-524 (1946) (appeal from order of confirmation); Ecker v. Western Pacific R. R., 318 U. S. 448, 506-509 (1943) (appeal from order of approval); In re Chicago, R. I. \& Pac. R. R., 160 F. 2d 942, 947-949 (C. C. A. 7th 1947) (order refusing to confirm and remanding with instructions, vacated); In re New York, N. H. \& H. R. R., 147 F. 2d 40, 45-46 (C. C. A. 2d 1945) (appeal from order of approval). In the Missouri Pacific proceeding the Commission, in response to a request of the Eircuit Court of Appeals for the Eighth Circuit, stated that in its view the retirement of debt with resultant release of new securities, extensive expenditures for improvements and large cash accumulations subsequent to its October 1944 report justified further Commission review of the plan. In September 1947 that Court vacated the District Court order of approval and directed that the plan be returned to the Commission "for its further investigation, consideration and recommendation." Wright v. Group of Institutional Investors, 163 F. 2d 1022 (C. C. A. 8th 1947).

A procedure, which may become the exclusive procedure for urging reconsideration of a $\$ 77$ plan on the ground of "changed conditions," is that contained in P. L. 478, 80th Congress, for obtaining Commission reconsideration of certified plans (id. \$3).

151. See discussion supra.

152. Railroad receiverships during the period 1870-1897 were of an average duration of two to three years. Swain, Economic Aspects of Railroad Receivership, $3 \mathrm{~J}$. Arr. EcoN. Ass'N 53, 104 (1898). The 225 railroad receiverships that took place in the period 1898-1931 were of an average duration of four years, five months. 2 DEwING, THE FINANCIAI POLICY OF CORPORATIONS $1321 \mathrm{n}$. ccc (1941); $c f$. Rodgers and Groom, supra note 13 , at $571 \mathrm{n}$. 1. The average time consumed in $\$ 77$ proceedings of class I roads up to June 1,1948 is as follows :

14 proceedings instituted under $\$ 77$ and completed............. 9 yrs., $1 \mathrm{mo}$.

5 proceedings instituted under $\$ 77$ but not yet completed..........11 yrs., 6 mo.

1 proceeding transferred from equity to $\$ 77$ and completed..........13 yrs., $7 \mathrm{mo}$.

4 proceedings transferred from equity to $\$ 77$ but not yet completed.. 5 yrs., 3 mo.

153. Craven and Fuller, stipra note 16, at 1263. See Group of Institutional Investors v. Chicago, M., St. P. \& Pac. R. R., 318 U. S. 523, 545 (1943) ; In re Chicago, R. I. \& Pac. Ry., 72 F. 2d 443, 452 (C. C. A. 7th 1934). But see Lowden v. Northern Nat1. Bank \& Trust Co., 298 U. S. 160, 164 (1936). 
$\S 77$ petitions were filed in large numbers, there was no suggestion that the proceedings would be used as a means of securing a moratorium. ${ }^{154}$ But that very thing was accomplished in at least one instance. ${ }^{155}$ To the extent that $\S 77$ is regarded as a vehicle for reducing railroad capitalization ${ }^{156}$ and fixed charges, this objective is defeated by dismissal of the proceedings.

\section{Recent Legislative Proposals 'Relating to Section 77}

Stockholders and junior creditors who were excluded from participating in roads reorganized under $\$ 77$ have been vocal in expressing dissatisfaction with the statute. Beginning in 1943, juniors sought to amend $\S 77$ so as to nullify those holdings of the Western Pacific and Milwaukee cases recognizing prospective future earnings as the primary basis for determining capitalization of the reorganized road. They sought to establish seemingly arbitrary levels below which capitalization could not be reduced. ${ }^{157}$

When this proposal failed to pass the Senate, juniors sought enactment of a bill which would require that court control of roads undergoing $\S 77$ reorganization be surrendered to the debtor if average annual earnings for seven preceding years were adequate to meet fixed charges. The debtor would then be given the opportunity for "readjustment of its financial structure as in the light of present ... circumstances may be consistent with sound financial practice." 158 This proposal, when introduced, contemplated that readjustment would be of the Chapter XV form, heretofore described, or by voluntary agreement or extension. Thus would be provided an escape from much of the restriction of priority. There was a flurry of other bills ${ }^{159}$

154. A petition so filed might be subject to dismissal for not having been filed in "good faith." See In re Realty Associates Securities Corp., 163 F. 2d 387, 391 (C. C. A. 2d 1947).

155. The St. Louis, Southwestern proceedings were dismissed July 24, $1947 . C f$. Boston Terminal Co. v. Mutual Savings Bank Group Committee, 127 F. 2d 707 (C. C. A. 1st 1942). A similar result has been accomplished under Chapter X, e. g., Iit re Realty Associates Securities Corp., 163 F.'2d 387, 390-391 (C. C. A. 2d 1947).

156. See discussion supra.

157. This was the objective of the Hobbs Bills of the 78th Congress. [H. R. 2857 and $H$. R. $4960 ;$ Hearings before House Committee on Judiciary on $H$. $R .2857$; H. R. Rep. No. 1615 (1944)] and the 79th Congress [H. R. 37; H. R. REP. No. 48].

158. This was the objective of the Reed Bill of the 79th Congress H. R. 4779 and H. R. 5924, Hearings before Honse Committee on Judiciary on $H$. R. 4779, H. R. REP. No. 1838 .

159. (a) The Wheeler Bill of the 79th Congress [S. 1253 as reported with amendments April 11, 1946; SEN. REP. No. 1170; Hearings before Senate Committee on Interstate and Foreign Commerce on $S .1253,135$ et seg. (1946); H. R. ReP. No. 2691]; (b) the Reed-Myers Bill of the 80th Congress [Hearings before Senate Committee on Interstate and Foreign Commerce on S. 249; SEN. ReP. No. 432 (parts 1 and 2) ]; and (c) the Reed Bill of the 80th Congress [H. R. 3237 and H. R. 3980; Hearings before House Committee on Judiciary on H. R. 3237; H. R. ReP. No. 923 (parts 1 and 2) ]. 
with multiple objectives but whose certain result would be effective curtailment of $\S 77$ as a railroad reorganization statute. ${ }^{160}$ Seemingly, inspiration for these latter measures stemmed largely from Chapter XV which, when enacted, was thought to be so limited that it could not affect $\S 77$. Failure of enactment of these bills at a time when railroad earnings were at a peak engenders the feeling that the general pattern of $\S 77$ will remain. ${ }^{161}$

\section{Section 77 and Diligent Reorganization}

Other than the objections of juniors, the chief criticism of $\S 77$ is the delay in accomplishing reorganization. Some of this delay is understandable. For the same reasons that state legislatures enacted moratorium and stay laws, the ICC did not push plans when earnings were at a low level. It would have been impolitic for senior creditors to have urged speed at this stage, and juniors had every interest in securing delay. In addition, the most serious legal problems of the statute were not conclusively answered until the Supreme Court decisions of March 1943. Thus, unheeded went the early admonition of that Court, that " . . . those who institute the [\$77] proceeding and those who carry it forward . . . [are] bound to exercise the highest degree of diligence. . . ." 182

Much of the delay subsequent to the late thirties may be attributed to the reorganization scheme contemplated by the statute. Although corporate reorganization developed in America exclusively as a function of the courts, it was long recognized that it might be delegated by statute to an administrative agency, with recourse to the courts only to determine compliance with statutory standards. ${ }^{163}$ While $\S 77$

160. None of the bills cited in notes 157-159 supra had ICC support. In the midst of the flurry there was introduced, at the request of the ICC, a bill supposedly to enable solvent roads to eliminate the "threat of financial difficulties" and thus avoid $\$ 77$ reorganization. For an analysis of this proposal, see Billyou, Corporate Mortgage Bonds and Majority Clauses, 57 YALE I. J. 595 (1948). The Commission proposal led to enactment of P. L. 478, 80th Cong., ist Sess. (1948).

161. Contrariwise, the persistence and nature of criticism of $\$ 77$ since 1943 , the failure of the Commission or senior creditors to present a reasoned defense of the section, and proposal by the Commission of a statute that flies in the face of present reorganization law [see note $160 \mathrm{supra}$ ] may indicate that the days of $\$ 77$ are numbered.

162. See Continental Illinois Nat. Bank \& Trust Co. v. Chicago, R. I. \& Pac. Ry., 294 U. S. 648, 685 (1935).

163. More than half a century ago Judge Taft made such a suggestion as to railroad reorganizations. ANN. REP., AMr. BAR Ass'N 237, 264 (1895). This view was adopted in the Bank Conservation Act of 1933 which empowers the Comptroller of the Currency to appoint a conservator for insolvent national banks and for the implementation, without judicial approval, of a reorganization plan approved by the Comptroller. 48 STAт. 1 (1933), 12 U. S. C. $\$ 207$ (1940). That this view is not likely to receive wide acceptance in the near future seems clear from the observation made by the SEC in 1937 and 1940 that it did ". . not believe there is any present necessity that they [the courts] should be divested of control over and responsibility for the administration of these [insolvent] estates by placing the functions which they 
was adopted before the Roosevelt Administration took office, there was agreement between the incoming and outgoing administrations as to the need for a statute which would inject the ICC into the reorganization process. ${ }^{164}$ There were differences as to details; one was the scope of the Commission role. A proposal that railroad reorganization be vested exclusively in the Commission ${ }^{\mathbf{1 6 5}}$ did not survive to be included in the bill which finally became $\S 77$. In the 1935 revision of $\S 77$, scant attention was paid to the relative roles of court and Commission, so that their relative position today substantially reflects the compromise of $1933 .^{168}$

Briefly put, in this role the Commission, after hearings, approves a plan which it certifies to the district court. If that court finds that the plan conforms to statutory requirements it may approve it. Its only alternative, save for what it may be able to do under the guise of "curing defects, supplying omissions or reconciling inconsistencies," 167 is to refuse approval and remand the plan to the Commission. ${ }^{168}$

In 1937, subsequent to an extensive study of protective and reorganization committees, ${ }^{169}$ and again in $1940,{ }^{170}$ the SEC, as its studied conclusion, stated: "We do not believe that there is any present necessity that. . . [the courts] should be divested of control over and responsibility for the administration of these [insolvent] estates by placing the functions which they perform in the hands of administrative agencies. Nor do we believe such control and responsibility over these estates should be shared by the courts and the administrative agencies. Rather, we recommend that the powers of the courts over these estates be broadened, that they be provided with further and more specific standards to guide their administration of them, and that machinery

perform in the hands of administrative agencies." SEC, REPORT ON THE STUDY AND Investigation of the Work, Activity, Personnel and Functrons of Protective and Reorganization Conmitiees, pt. I, 898 (1937); id. pt. VIII, 336 (1940).

164. N. Y. Times, June 8,1935 , p. 25 , col. 3.

165. 76 Cong. REc. 2927, 5358 (1935).

166. $\$ 77$ incorporates time-consuming provisions, included in 1933 and 1935 , to meet supposed constitutional problems. For example, it provides for court order of approval followed by balloting by the ICC which, in turn, is followed by court order of confirmation. This results in two court hearings involving substantially similar questions with the right to appeal from each order. Since the decision of the Supreme Court in Reconstruction Finance Corp. v. Denver \& R. G. W. R. R., 328 U. S. 495 (1946), indicating that an adverse result in balloting of security holders cannot prevent confirmation of an approved plan, the suggestion has been made that balloting provisions be eliminated from $\$ 77$, ANN. ReP., C'TTEe on BANkRUPTCY AND Corporate: REORGANIZATION, Ass'N OF THE BAR OF THE CITY OF N. Y. 7 (1946-1947). With balloting eliminated, a confirmation hearing would serve no useful purpose.

167. See note 143 supra.

168. See note 142 supra.

169. SEC, supra note 163 , pt. I, 898.

170. Id. pt. VIII, 336. 
be designed to afford the courts the benefits of administrative assistance in these complicated financial and business situations." In the light of this, the $\$ 77$ pattern of allocating extensive duties to the ICC would seem to deserve reconsideration.

Thought-provoking contrasts with the roles assigned Commission and court by $\S 77$, are provided by Chapter X of the Bankruptcy Act and $\S 11$ of the Holding Company Act. Under Chapter $X,{ }^{171}$ enacted in 1938, reorganization is almost exclusively judicial. The statute provides for SEC participation in two ways: first, as a party on the request, or with the approval, of the judge; ${ }^{172}$ second, in the form of the duty to render advisory reports to the judge on plans which he deems worthy of consideration when scheduled liabilities exceed \$3,000,000 and, when less than that sum, on the request of the judge. ${ }^{173}$ This participating role, wherein the SEC has no veto power over plans, substantially reflects the recommendations made by that Commission prior to the drafting of Chapter $\mathrm{X}^{.174}$

The Holding Company Act, ${ }^{175}$ enacted one day prior to the 1935 revision of $\S 77,,^{176}$ providing in $\S 11$ for approval and implementation of plans for simplification of corporate structure, redistribution of voting power, and reorganization of solvent companies subject to the Act, ${ }^{177}$ embraces a different commission-judiciary role. There, as to solvent companies, the SEC may approve a plan sponsored by security holders or proposed by the Commission. ${ }^{178}$ Only after SEC approval are proceedings initiated before the court-when the SEC seeks an order directing enforcement of, or compliance with, the approved plan. ${ }^{179}$ On entry of the order, which issues if it is found that the plan complies with statutory standards, the plan is effective upon the company and security holders. In the case of corporations subject to the Holding Company Act and undergoing Chapter $\mathrm{X}$ re-

171. 52 Stat. 883 (1938), 11 U. S. C. $\$ 501$ et seq. (1940). Conditions deemed relevant by the Commission in determining whether it should, of its own motion, participate in Chapter $X$ cases are: (1) the statutory evidence that Congress did not desire that the SEC participate in all Chapter $X$ proceedings, (2) the existence, in the case, of matters of public interest and whether they alone, or with other factors and circumstances, warrant SEC participation. Address, Samuel O. Clark, Jr., Director of the Reorganization Division, SEC, Jan. 5, 1939, p. 9.

172. 11 U. S. C. $\$ 608$ (1940). However, unlike other parties, the Commission may not appeal.

173. $I d$. $\S 572$.

174. SEC, supra note 163 , pt. I, 898-901; $i d$. pt. VIII, 336 n. 12 . The SEC did not suggest that it be deprived of the right to appeal.

175. 49 Stat. 803 (1935), 15 U. S. C. $\$ 79$ (1940).

176. The Holding Company Act was enacted Aug. 26, 1935.

177. 49 Stat. 820 (1935), 15 U. S. C. $\$ 79 k$ (b) (1940).

178. Id. (b) and (e).

179. $I d$. (d) and (e). 
organization, no plan may become effective unless it receives SEC approval. ${ }^{180}$

On their face, these statutes evince different policies as to the administrative role in reorganization. Chapter $\mathrm{X}$ evinces a desire (a) to make available to the courts expert and impartial assistance in determination of the complex problems arising in the course of proceedings, or in connection with plan formulation without giving the SEC the power to veto, or require, the adoption of any particular plan; and (b) to assign to the SEC the duty of observing Chapter $\mathrm{X}$ proceedings ${ }^{181}$ and to participate when it believes conditions warrant.

As a former Director of the Reorganization Division of the SEC put it: "Since we have been clothed with no sanctions to enforce our findings on particular issues nor to make binding upon the courts or the parties the conclusions expressed in our advisory reports upon plans of reorganization, we can make our influence felt only through the quality of the assistance and advice that we render in the proceedings. In other words it is incumbent upon is to proceed with full knowledge that from a long range viewpoint our views will find acceptance only by virtue of the inherent soundness they possess." ${ }^{182}$ In contrast, $\S 11$ evinces a desire that the views of the SEC prevail in such proceedings and in those Chapter $\mathrm{X}$ proceedings involving companies subject to the Holding Company Act.

Despite the difference in attitude expressed by Congress in the two statutes, Judge Frank, then Chairman of the SEC, expressed the view that the recognition accorded SEC participation in Chapter $\mathrm{X}$ reorganizations and the results accomplished, justified serious consideration of the possibility of recasting the SEC $\S 11$ role along the lines of Chapter $X^{183}$ These views, expressed by the SEC chairman shortly after it had acquired experience under both statutes, deserve serious consideration. Justification for the views expressed were that the SEC reports, which were "advisory only," received such approbation that they were "having an immense effect on the substantive law of corporate reorganizations." Further, there was the decided feeling that the diligence displayed in Chapter $\mathrm{X}$ proceedings was in marked contrast with that under $\S 11$ and $\S 77 .{ }^{184}$ No doubt, acceptance of the SEC's views of substantive

180. Id. (f).

181. This is facilitated by the Chapter $X$ provision requiring the clerk of the court to transmit to the SEC copies of petitions, orders and other documents filed in such proceedings. 52 STAT. 903 (1938), 11 U. S. C. $\$ 665$ (1940).

182. Clark, supra note 171 at 8.

183. Ltr. July 9, 1940, to Waiter Gellhorn, Director, Attorney General's Committee on Administrative Procedure, reproduced in SEN. Doc. No. 10, Part 13, 132136 (1941).

184. Id. $132-133$. 
law was facilitated by a receptive judiciary. Most significant is the fact that on the basis of experience the SEC suggested that its $\S 11$ prerogative, to hold hearings and to approve a plan in advance of judicial consideration, might be surrendered without impairing statutory objectives. The foregoing suggestions and the supporting reasons are equally applicable to the ICC role in railroad reorganization. Assuming agreement that the ICC continue to have the final word on all matters dealing with feasibility of plans, including capital structure, as contrasted with matters dealing with fairness, ${ }^{185}$ this might well be accomplished by a Commission report made at the close of court hearings on proposed plans. ${ }^{186}$

It is unlikely that the well-being of any field of American corporate endeavor has greater repercussions than that of the railroads. No state or county or financial institution is isolated from the effects of the insolvency of the roads. This is particularly true since service deteriorates as insolvency approaches, and it is the rare case where service or equipment attains a high standard while in reorganization. Since 1943, revision of the railroad reorganization statute has been much discussed in many places, particularly in the hearing and committee rooms of Congress. Much of this, unfortunately, appears to have been misdirected. Activity has been directed chiefly to enlarging the group of those who may participate in future reorganizations. While this is not necessarily an undesirable endeavor, concentration of interest along these lines has caused such dissipation of time and effort as to defer needed revision of a statute which is today procedurally archaic. Section 77 can be effectively revised. However, aspiring revisors should recognize that railroad reorganization involves more than questions as to who may participate in a reorganized road and that it is but one aspect of the greater problem of creating and maintaining railroad systems that will adequately serve the future.

185. Cf. "It may well be that, without harm to the standards of $\S 77$ greater speed could be obtained if, by amendments to the Act, the Interstate Commerce Commission, vis a vis the fairness of railroad reorganization plans as distingtuished from their feasibility, were assigned a role similar to that played by the Securities and Exchange Commission in corporate reorganizations under Chapter $X$, i. e., as adviser to the court and the interested parties." Frank, J., in New England Coal \& Coke Co. v. Rutland R. R., 143 F. 2d 179, 188 n. 30 (C. C. A. 2d 1944).

186. Thus, eliminated, in addition to the Commission hearing, would be the time consumed between the Commission hearing and the ensuing court hearing, a period which not infrequently is at least one year. Also eliminated, would be the dilatory procedure of incorporating in the court record matters which could have been, but were not, presented before the Commission [Cf. Comstock v. Group of Institutional Investors, $163 \mathrm{~F}$. 2d 350 (C. C. A. 8th 1947) ], a procedure sharply curtained in $\$ 11$ proceedings by specific statutory provision. 49 STAT. 834 (1935), 15 U. S. C. \$ 79x (1940). 